\title{
The requirements for implementing school accreditation in development schools for girls in Tabuk in the light of international and A rab experiences
}

\section{Mona Saad Al-Omari}

Assistant principal in Tabuk Education Department, Kingdom of Saudi Arabia

\section{Eman Khalil Al-Hindi}

Teacher in Tabuk Education Department, Kingdom of Saudi Arabia Dr. Mohammed bin Othman Al-Thebaiti

Associate professor at educational administration and planning department, Umm al-Qura University

Abstract:

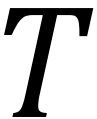

he current research aimed at identifying the degree of importance the requirements of implementing school accreditation in development schools for girls in Tabuk from the viewpoints of principals of development schools and the supervisors of development and quality, and to determine the differences of the statistically significant differences between the mean scores of the importance degree of the requirements of implementing school accreditation in development schools for girls in Tabuk from principals of development schools and quality and development supervisors point of view according to the nature of work and years of experience. The descriptive survey method was utilized, participants were (30) principals of the development schools and (17) supervisors of Development\& Quality in Tabuk. Findings revealed that the participants' response to all dimensions was high with a general mean: $(2,83),(2,76),(2,71),(2,67)$, $(2,50)$ respectively. Findings revealed no statistically significant difference for the responses related to the variables: nature of work and years of experience.

Keywords: School Accreditation - Development Schools Arab and International Experiences.

\section{Introduction:}

Education reforms have been paid a major concern in various countries of the world in the light of the rapid and 
successive changes and developments that our world is witnessing today in all fields. Global interest has increased significantly in the last two decades of the twentieth century with the Quality of Education (QE); due to low levels of $(\mathrm{QE})$. This is evident in the low level of the educational product and lack of communication between educational institutions and society (Ziadat, 2007: 249).

If educational institutions have to face current and future problems and challenges, Officials should realize that "quality system and school accreditation" has become a fundamental requirement to raise the efficiency of schools and improve the performance of employees.

Many countries have made efforts in the field of school accreditation (SA) as in America, the United Kingdom, Japan, Egypt and Qatar, and have developed models that have resulted in a change in their school outcomes (ElSherbiny, 2017: 127),

In this regard, the Custodian of the Two Holy Mosques King Abdullah bin Abdulaziz, in a speech at the first international conference (7/1431 AH) in Riyadh, called to adopt national standards for quality to be an indication of the efficiency of the Saudi educational system. This is what the King Abdullah bin Abdulaziz Project seeks to develop public education, as it aims to develop all public education schools in Saudi Arabia, so that they become ready to the requirements of life in the twenty-first century (Al-Shehri, 2013: 2).

\section{Problem of the research}

Despite the great efforts exerted by the Ministry of Education in order to improve the educational process and ensure its quality, there is still a lack in quality in school performance, which is directly reflected in its educational outcomes. Higher education institutions and other work 
sectors are still unsatisfied with the public education outcomes because of its failure to meet their expectations (Hamda Al-Maliki, 2010: 6).

This makes us pay attention to the quality of educational outcomes and strive to improve them and align them with the needs of the labor market to achieve economic growth and encourage sustainable development (Al-Madani, AlOmari, 2013: 279).

Implementing quality and accreditation requirements is one of the supporting mechanisms to ensure (QE) provided by these schools and has become a demand imposed by the urgent need for high educational quality (Azab and Morsi, 2010: 254).

Many countries have made efforts in the field of school accreditation as in America, the United Kingdom, Japan, Egypt, and Qatar, and have developed models that have resulted in a change in their school outcomes (El-Sherbiny, 2017: 127).

Based on the foregoing, the current research tried to identify the requirements of applying school accreditation in the light of international and Arab experiences, and the importance degree of each from principals of development schools and quality and development supervisors' point of view.

The problem of study could be determined by the following main question: What are the requirements for implementing school accreditation in development schools for girls in Tabuk in the light of international and Arab experiences? It is subdivided into the following sub-questions:

1. What is the importance degree of the requirements of implementing school accreditation in development 
schools for girls in Tabuk from principals of development schools and quality and development supervisors' point of view?

2. Are there statistically significant differences between the mean scores of the importance degree of the requirements of implementing school accreditation in development schools for girls in Tabuk from principals of development schools and quality and development supervisors' point of view attributable to the nature of work and years of experience?

\section{Goals of the research}

1. Recognizing the importance degree of the requirements of implementing school accreditation in development schools for girls in Tabuk from principals of development schools and quality and development supervisors' point of view.

2. Identifying the statistically significant differences between the mean scores of the importance degree of the requirements of implementing school accreditation in development schools for girls in Tabuk from principals of development schools and quality and development supervisors' point of view attributable to the nature of work, years of experience.

\section{Importance of the research}

- Keeping up with Arab and international attention to the requirements of quality and school accreditation.

- Coinciding with the implementation of the King Abdullah project in development schools to raise the quality of Saudi education.

- Attracting the attention of those in charge of public education to the necessity of applying school 
accreditation and identifying its most important requirements in girls' development schools.

- Emphasizing the importance of implementing school accreditation in public education schools in the Kingdom of Saudi Arabia.

\section{Limitations of the research:}

- Objective limitations: To shed light on the requirements of school accreditation in some Arab and international countries and make use of them to determine the requirements for implementing school accreditation in development schools for girls in Tabuk.

- Human limitations: Supervisors and Principals of Quality and Development in development schools for girls in Tabuk.

- Spatial limitations: Development schools for girls in Tabuk.

- Time limitations: The first semester of the academic year $1435 \mathrm{AH}-1436 \mathrm{AH}$.

\section{Terminology of the research:}

1- School Accreditation: It is the process of external evaluation of quality that is used by education at all levels, and works in the light of the quality standards that aim to improve the quality of inputs, processes, outputs, management, and services provided (Derandy \& Hook, 2007: 246).

The school accreditation is procedurally defined as: Granting the educational institution a formal recognition by a national organization of school accreditation at the Ministry of Education that it has fulfilled the required conditions and specifications, provided that this is done according to pre-determined criteria, and that it is sufficient to achieve educational quality. 
2- Quality Assurance System: A set of procedures to ensure that the quality control process is carried out in accordance with a future plan that has met the conditions and technical specifications (Azab, Morsi, 2010: 276).

The Quality Assurance System is procedurally defined as: A way to ensure that there are no errors whenever possible, and to ensure that the required specifications and standards have been met from the first time.

3- Development schools: These are the schools that implement the King Abdullah bin Abdulaziz Project for the Development of public Education Schools, which is represented in the "School Development Model", which represents a road map for developing all schools according to a systemic vision to achieve specific features in the learner (Guidance for the educational supervision in the school development model, 1433 AH: 6 ).

The Development schools is procedurally defined as: The schools that implement the King Abdullah bin Abdulaziz project, which are proceeding in a gradual development, include the educational system in all its aspects.

\section{The theoretical framework of research:}

\section{First Topic: School Accreditation:}

\section{Definition of School Accreditation:}

School Accreditation is "a mechanism that aims to improve the quality of education in educational institutions, as it is an effective tool to ensure a certain level, standards and quality" (Hussein, 2009: 6). It is also known as "a set of standards and procedures that determines how educational institutions meet the professional standards for the quality of academic programs" ( Gollnick, 2003 AD: 313).

\section{The relationship between quality and accreditation:}

Quality is closely related to accreditation. Implementing quality and accreditation in educational institutions leads to 
efficiency in the educational process, and then meeting the needs of society. Accreditation has been defined as a way to achieve quality and ensure it as an ongoing assessment of the quality of the educational level in the school, Encouraging the educational institution to confirm its identity, quality, and development in light of a set of clear and agreed upon basic standards, and thus obtaining educational accreditation (Al-Madani, Al-Omari, 2013: 281).

Based on the foregoing, Accreditation is inherent in quality assurance in education, as quality paves the way for accreditation, and accreditation measures the extent to which quality has been achieved in those educational institutions.

\section{The importance of school accreditation:}

The importance of accreditation can be fully expressed in: Motivating the school to conduct the self-evaluation process and improve its system, achieving the unity of the profession by bringing together practitioners, academics and students in one directed activity, improving professional services according to changes in the field of knowledge and applied practices, ensuring an external evaluation of educational institutions in line with modern policies and directives in education (Abdo, 2013: 480).

The current research concluded that the importance of school accreditation lies in ensuring quality in public education schools, and improving their outputs to keep pace with the requirements of the times and the needs of the labor market.

\section{Second Topic: Development schools}

They are the schools that apply the King Abdullah bin Abdulaziz project, which is one of the most important projects that aimed to develop school performance in 
public education in all its aspects. This project aims to develop and raise the level of education in the Kingdom.

\section{The pillars on which the development schools are based:}

School leadership and management: The school's success in performing its mission depends on the presence of influential leadership that professionally motivates others to successful work, characterized by a culture of cooperation and sharing. Achieving these goals depends on the level of success in building educational principals who need a lot of efforts and capabilities.

The school environment focuses on improving the environment that encourages students to the educational achievement and helps them achieve learning outcomes. In the plan, goals are set to improve the school environment.

The curriculum and its teaching method aims to support students' learning and achieve the desired expectations, and each applied curriculum has what is called "the curriculum document" that defines learning expectations (learning outcomes) in each grade and subject.

School activities, additional programs and counseling. It is based on developing extracurricular activities and social, counseling, psychological and health services. The effective school plan takes into consideration all educational and non-educational services provided to school students.

Professional development: Helping teachers to create desirable skills and attitudes and develop their capabilities, which leads to raising their level of performance. This axis is one of the most important dimensions that the school development plan will include. The school plan cannot succeed if it does not care to develop the professional growth of its employees through targeted training and mentoring programs. 
Family and Society: The school is an integral part of society, which senses its problems and always strives towards its growth and development. Some research indicates that the participation of parents -in particular- is one of the most important factors that contribute to the success of the children in the school. Therefore, the school should work to develop the relationship with the surrounding environment so that the school plan includes a set of programs that aim to strengthen the school's relationship with the family and its local community (Ministry of Education, 1433 AH: 111-112).

It is clear from what was included in the King Abdullah project and the efforts made in the "development" project, the great interest in education in the Kingdom of Saudi Arabia with a view of developing and improving education and seeking to improve its outputs, which makes it important to find an appropriate mechanism to evaluate and improve it and ensure the continuity of its development.

\section{The third topic: Arab and international experiences in} school accreditation and quality assurance:

\section{The Experience of United States of America:}

The United States of America is one of the leading countries in school accreditation and educational quality assurance (Al-Turiri, 2013: 32). The most important requirements for school accreditation and quality assurance in America are as follows: vision, a new organizational structure based on collective decision-making, reflection on past practices on improving, current practices, and comparing school performance with the performance of other accredited schools, the participation with the local community, the existence of a system for evaluating performance through which the school evaluates its performance and external evaluation, ensuring a school climate characterized by commitment, responsibility, 
cooperation, participation, communication and thinking (Al-Nabawi, 2006: 166).

\section{The experience of the United Kingdom:}

Educational institutions in the United Kingdom have a high academic reputation. The British Accreditation Council was established for accrediting educational institutions. This organization evaluates the educational institution's fulfillment of the criteria set by the British Council. This organization has set several requirements for developing the quality and school accreditation system represented in: content design and curriculum organization, teaching and learning methods and assessment methods, student progress and achievement, student guidance and counseling, learning resources, and continuous quality assurance (Sharif, 2011: 163).

\section{The experience of Japan:}

The most important characteristic of the Japanese experience is the cooperation between the institution and its ministry, and the accreditation organization in achieving educational quality and obtaining accreditation (Azab, Morsi, 2010: 304). There are several requirements for achieving school accreditation in Japan, namely: the goals of the educational institution and its organizational entity, administrative procedures and systems, developing institutional systems and organizing teaching processes, the quality of students, life and school, the educational process which is represented in the curriculum and available capabilities (Al-Shall, Emara, 2008: 341 ).

\section{The experience of Egypt:}

The Egyptian experience is a pioneer in the field of establishing a school accreditation system. The Ministry of Education imposed a national slogan that emphasizes "quality for all". From this standpoint, it is possible to 
address the requirements of quality and educational accreditation for public education in Egypt, which started with: the clear vision, mission and goals that aimed at meeting the requirements of educational accreditation and translating them into plans for improvement, concrete support that contributes to raising and improving the level of education and helps in the introduction of modern technologies (Chilwan, 2007: 9 ). Requirements also include finding effective school administration capable of making a change in the educational process, absorbing the requirements of quality and accreditation, and establishing an appropriate infrastructure, activating sustainable community partnership that makes schools "open institutions" to the community (Nada, Shihna, 2013: 59).

\section{The experience of Qatar:}

School accreditation in the State of Qatar aims that every student receive education at the required level according to their needs, and in accordance with the criteria for high achievement through the support that school programs receive to develop learning outcomes. The National School Accreditation Authority in Qatar has set requirements for obtaining school accreditation which are as follows: * the school has to meet the following requirements: a clear vision and goals, a clear curriculum to achieve the school's vision and goals, an administrative system undertaken by officials responsible for providing appropriate support, guidance and supervision to all school programs in general, a sufficient and appropriate budget that supports school stability, necessary accommodation and facilities, and development programs for school personnel, a school plan to achieve student goals, and other plans to assess the level of progress in achieving these goals, plans for extracurricular activities that are implemented and strengthened as possible. Available at http://cutt.us/Rxha, dated 9/6/2014. 
School accreditation requirements can be drawn from previous Arab and international experiences in the following dimensions:

1. Effective School Leadership, includes: Adoption of a vision, mission and goals for continuous improvement and development. Setting strategic plans for the improvement process, as well as establishing a good infrastructure and organization for development processes and improvement of work.

2. The appropriate school environment: has the appropriate physical capabilities of facilities and equipment, and a good organizational climate based on cooperation and participation.

3. Teaching and learning processes, include:

o The teacher: his performance and ability to use modern technologies and methods of measurement and evaluation, professional and self-development.

o The Student: Improving student's achievement through a variety of assessment methods, and activating learning strategies.

o The Curriculum: Presenting the curriculum in an attractive way that includes all of its educational and learning goals, and employs modern technologies.

4. Community partnership: Activating the partnership between the school and the community, according to prepared plans that include various programs.

5. Evaluation and accountability: Identifying errors, accountability and diversity in the methods of evaluation, as the school evaluates itself and then an external party evaluates it. 


\section{Previous Studies}

\section{First: Arabic studies}

1- Al-Medawi study (2013) entitled "A proposed mechanism for applying the standards of the school accreditation system in public education institutions for secondary schools in the Kingdom of Saudi Arabia in the city of Abha, in Asir region." The study aimed to identify the standards of the school accreditation system in public education institutions in the Kingdom of Saudi Arabia, and to discover the obstacles to its implementation. The descriptive analytical method was utilized, participants were (10) principals of the secondary stage in public education, (20) assistant principals, (50) female teachers and (100) female students at the secondary stage. The researchers used a questionnaire as a tool for gathering data. Findings revealed* no activation of community partnership in the educational process. * The field of organization and management in general does not face practical obstacles in school. * The field of the school environment faces practical obstacles * Teacher's lack of interest in activating the extra-curricular activities among female students.

2- Al-Rayes study (2013) entitled "A future strategic plan for school accreditation (importance, reasons, and obstacles) aims to identify: the importance of developing a future strategic plan for school accreditation, by defining the concept of school accreditation, the importance of implementing this plan, and identifying obstacles to its implementation. The descriptive analytical method was utilized. Findings disclosed that: * School accreditation emphasizes the importance of participation in designing the school plan by all its employees * 
Encouraging schools to perform self-evaluation in order to ensure continuous development, through adopting internal evaluation criteria for the school.

3- Al-Sakhil study (2010) entitled "School-centered reform and preparing it for educational accreditation as one of the dimensions of the national strategic plan for pre-university education (a field study) in Dakahlia Governorate" The study aimed to highlight the most important foundations of school-centered reform in light of global experiences, the researcher used the descriptive survey method. Instruments included a questionnaire for gatheringdata. The researcher carried out a pilot study in (22) schools that are nominated for educational accreditation in Dakahila Governorate. Findings revealed the following: The efficient manager is the one who plans well, and does not depend on individualism, but rather pursues work within the team.* The principal of the school performs his roles, including the distribution of responsibilities and Defining tasks for all school personnel.* The importance of using knowledge in life fields.

4- Al-Shall\& Emara study, (2009) entitled "Requirements of preparing basic education schools in Beheira Governorate to implement accreditation and quality assurance". The study aimed to develop a proposed vision of the requirements of preparing basic education schools in Beheira Governorate for accreditation and quality assurance in the light of experiences of some developed countries. The researchers used the descriptive survey method, participants were 18 schools' principals and agents in all educational departments in Beheira Governorate. Instruments included a questionnaire and personal interviews for gathering information. Findings 
revealed the following: * The need for audio-visual and other modern means of communication. * Encouraging self-censorship among school personnel.

\section{Second: Foreign Studies}

Hartley \&Virkus Study, (2003) entitled "Quality Assurance and Accreditation Experiences in the United Kingdom and Estonia" The study suggested a set of global experiences in the field of accreditation and quality assurance in both the United Kingdom and Estonia. The study shed light the difference in the concept of quality assurance and accreditation from one country to another due to the difference in foundations and what it seeks to achieve to improve performance and improve education. The study revealed a set of findings, the most prominent of which are: * The accreditation and quality assurance system in the United Kingdom depends on some internal and external procedures such as evaluation of teaching quality, educational programs, academic review and external evaluation, but in Estonia it is based on self and individual evaluation.

Pond Study (2002) entitled "Requirements for Achieving Quality in Education in the Twenty-first emphasized the importance of achieving quality assurance and accreditation in educational institutions in order to be able to keep pace with the changes that may occur in the twenty-first century. The study introduced the concepts of quality and their difference from state to state and from educational stage to another, the study also clarified some new directions for accreditation and quality assurance. A questionnaire was administered for data collection, and the descriptive survey method was utilized. Findings revealed the following: 
The necessity of providing and activating community partnership and funding the private sector of education.

\section{A commentary on the previous studies:}

A. The current study is similar to all previous studies in its focus on developing the level of education, and continuous improving in pre-university education institution. It also agreed with the study of (AlSakhil, 2010), (Al-Shall \& Emara, 2009) and (Pond, 2002) in their use of the descriptive method, and their use of the questionnaire as a tool to collect data. Finally, it also agreed with the study of (Al-Shall\& Emara,2009) in examining the requirements of implementing school accreditation in the light of international and Arab experiences.

B. The current study differs from the study of (AlMedawi, 2013) and (Al-Rayes 2013) in their use of the descriptive analytical method, and from the study of (Al-Rayes, 2013) that aimed to develop a future strategic plan for school accreditation, and the study of (Al-Madawi, 2013) that aimed to develop a proposed mechanism for implementing standards of school accreditation in public education schools at the secondary level, and the study of (Hartley $\&$ Virkus , 2003) that shed light on the different concepts of quality assurance and accreditation from one country to another due to the different foundations and what it seeks to achieve.

C. This study was limited to identifying the importance degree of school accreditation requirements in development schools in which the King Abdullah project for the development of public education is implemented. 


\section{Procedures of the research}

Methodology: The descriptive method was utilized.

Participants: The sample of the study consisted of (30) principals of the development schools in Tabuk, and (17) supervisors of development and quality.

The research sample can be described as follows:

Table (1)

\begin{tabular}{|c|c|c|c|}
\hline Variable & Variable Category & Number & Percent \% \\
\hline \multirow{4}{*}{ Nature of work } & Principal & 30 & $\mathbf{6 3 . 8 \%}$ \\
\cline { 2 - 4 } & Supervisor & 14 & $\mathbf{3 6 . 2 \%}$ \\
\cline { 2 - 4 } & Total & 47 & $\mathbf{1 0 0 \%}$ \\
\hline \multirow{4}{*}{$\begin{array}{c}\text { Years of } \\
\text { experience }\end{array}$} & $\begin{array}{c}\text { Lower than 10 } \\
\text { years }\end{array}$ & 3 & $\mathbf{6 . 4 \%}$ \\
\cline { 2 - 4 } & $\begin{array}{c}\text { From 10 to less } \\
\text { than15 }\end{array}$ & 7 & $14.9 \%$ \\
\cline { 2 - 4 } & $\mathbf{1 5}$ years or more & 37 & $\mathbf{7 8 . 7 \%}$ \\
\cline { 2 - 4 } & Total & 47 & $100 \%$ \\
\hline
\end{tabular}

Research Tool: The questionnaire: The current research depended on the previous studies conducted in the field of school accreditation. The questionnaire items were distributed over five dimensions: (effective school leadership, appropriate school environment, teaching and learning processes, community partnership, assessment and accountability).

Validity of the questionnaire:

- Face validity: It was presented to (6) faculty members specialized in the Department of administration and Planning. It consisted in its final form of (36) items distributed on the five dimensions.

- Internal consistency validity: Pearson's correlation of coefficient was calculated between the items and the field to which they belong. All correlation of 
coefficients are statistically significant at the level of (0.05), which indicates the strength of the internal consistency between each field of the study tool and the items to which they belong and thus is considered a strong indication of the instrument's validity to measure what was set to measure.

\section{Reliability of the questionnaire:}

The Alpha Cronbach equation was used, and it became clear that the values of the reliability coefficient ranged between $(0.78-0.86)$ for the five dimensions, and the value of the reliability coefficient of the tool as a whole was 0.85 , indicating that the tool has an appropriate degree of reliability.

\section{Findings, Explanation and Discussion:}

The first question: What is the importance degree of the requirements of implementing school accreditation in development schools for girls in Tabuk from principals of development schools and quality and development supervisors point of view?

Table (2) clarifies that the participants' response to all items was high with a mean $=(2,71)$. In the first place, the item (8) came with a high degree of importance,

with a mean $=(2.92)$. This is in accordance with Al-Sakhil study (2010) which indicated "the distribution of responsibilities and Defining tasks for all school personnel. Item (6) came in the last rank with a high degree of importance, with a mean $=(2.54)$, and this is confirmed by the Al-Rayes study (2013) which indicated the necessity of participating in designing the school plan by all school employees, as Al-Sakhil's study (2010) confirmed that the efficient principal is the one who plans well to achieve what his community expects, so it does not depend on the individualism, but teamwork. The research attributes these 
findings to lack awareness of some school principals about the importance of school staff participating in setting the school plan and their adherence to centralization. The remaining items ranged between $(2,88)$ and $(2.54)$.

Table (2) Means, standard deviations and ranks for participants' responses to: " effective school leadership"

\begin{tabular}{|c|c|c|c|c|c|}
\hline $\begin{array}{l}\text { Item } \\
\text { No. }\end{array}$ & Item & $\mathbf{M}$ & S.D & Rank & $\begin{array}{l}\text { Degree of } \\
\text { importance }\end{array}$ \\
\hline 8 & $\begin{array}{lr}\text { Designing } & \text { an } \\
\text { organizational } & \text { structure } \\
\text { that } & \text { identifies } \\
\text { responsibilities } & \text { within the } \\
\text { school. } & \end{array}$ & 2.92 & .34 & 1 & High \\
\hline 9 & $\begin{array}{lll}\begin{array}{l}\text { Forming } \\
\text { teams. }\end{array} & \text { school } & \text { work } \\
\end{array}$ & 2.88 & .39 & 2 & High \\
\hline 10 & $\begin{array}{l}\text { Achieving the principle of } \\
\text { empowering employees. }\end{array}$ & 2.86 & .40 & 3 & High \\
\hline 1 & $\begin{array}{l}\text { Leading vision } \\
\text { expressesthe future vision } \\
\text { of the school. }\end{array}$ & 2.84 & .47 & 4 & High \\
\hline 5 & $\begin{array}{l}\text { Developing strategic plans } \\
\text { for } \\
\text { improvement processes }\end{array}$ & 2.72 & .54 & 5 & High \\
\hline 2 & $\begin{array}{l}\text { The message seeks to } \\
\text { achieve the vision set for } \\
\text { the school }\end{array}$ & 2.70 & .51 & 6 & High \\
\hline 4 & $\begin{array}{l}\text { The goals of the school } \\
\text { are proportional to its } \\
\text { capabilities }\end{array}$ & 2.56 & .61 & 7 & High \\
\hline 7 & $\begin{array}{l}\text { Setting a professional } \\
\text { development plan for all } \\
\text { school staff }\end{array}$ & 2.56 & .64 & 8 & High \\
\hline 3 & $\begin{array}{l}\text { School staff participate in } \\
\text { setting the school vision. }\end{array}$ & 2.54 & .60 & 9 & High \\
\hline 6 & $\begin{array}{l}\text { School staff participate in } \\
\text { developing the school } \\
\text { plan. }\end{array}$ & 2.54 & .61 & 10 & High \\
\hline & Total & 2.71 & .37 & & High \\
\hline
\end{tabular}


Table (3):Means, standard deviations and ranks for participants' responses to:"Appropriate school environment"

\begin{tabular}{|c|c|c|c|c|c|}
\hline $\begin{array}{l}\text { Item } \\
\text { No. }\end{array}$ & Item & $\mathbf{M}$ & S.D & Rank & $\begin{array}{l}\text { Degree of } \\
\text { importance }\end{array}$ \\
\hline 6 & $\begin{array}{l}\text { Promoting citizenship trends } \\
\text { among school staff. }\end{array}$ & 2.88 & .39 & 1 & High \\
\hline 2 & $\begin{array}{l}\text { Availability of a healthy } \\
\text { climate in the classroom, such } \\
\text { as: ventilation, lighting. }\end{array}$ & 2.84 & .42 & 2 & High \\
\hline 3 & $\begin{array}{l}\text { Availability of security and } \\
\text { safety procedures inside the } \\
\text { school. }\end{array}$ & 2.82 & .44 & 3 & High \\
\hline 5 & $\begin{array}{l}\text { The school has a good } \\
\text { organizational climate for } \\
\text { exchanging reducational } \\
\text { experiences among its staff. }\end{array}$ & 2.74 & .53 & 4 & High \\
\hline 1 & $\begin{array}{l}\text { The classroom space is } \\
\text { suitable for student numbers. }\end{array}$ & 2.72 & .61 & 5 & High \\
\hline 4 & $\begin{array}{l}\text { Availability of modern } \\
\text { technical means such as: } \\
\text { computer, smart board, and } \\
\text { projector. }\end{array}$ & 2.68 & .51 & 6 & High \\
\hline 7 & $\begin{array}{l}\text { The school's database is } \\
\text { linked to the International } \\
\text { Information Network. }\end{array}$ & 1.98 & .77 & 7 & medium \\
\hline & Total & 2.67 & .36 & & High \\
\hline
\end{tabular}

Table (3) shows that the participants' response to all items was high with a mean $=(2,67)$. In the first place, the item (6) came with a high degree of importance, with a mean = (2.88). The research The researchers attribute these findings to the feeling of citizenship and affiliation that increases the productivity of female school employees and enhances their educational role, and this was confirmed by the policy of the education system in the Kingdom and stipulated in the model of development schools that "preserves the values of citizenship and positive habits of the Saudi society and its culture" (Ministry of Education, 1433 AH: 29). Item (7) came in the last rank with a medium degree of importance, with a mean $=(1.98)$. The 
research attributes this to the lack of information and communication technology infrastructure at the international level.The remaining items ranged between $(2,84)$ and $(2.68)$.

Table (4):Means, standard deviations and ranks for participants' responses to:"Teaching $\&$ Learning processes"

\begin{tabular}{|c|c|c|c|c|c|}
\hline $\begin{array}{l}\text { Item } \\
\text { No. }\end{array}$ & Item & $\mathbf{M}$ & S.D & Rank & $\begin{array}{c}\text { Degree of } \\
\text { importance }\end{array}$ \\
\hline 4 & $\begin{array}{l}\text { Engaging female students in } \\
\text { various educational activities. }\end{array}$ & 2.80 & .45 & 1 & High \\
\hline 5 & $\begin{array}{l}\text { Linking the curriculum to the } \\
\text { students' life fields. }\end{array}$ & 2.80 & .45 & 2 & High \\
\hline 3 & Providing feedback to students. & 2.78 & .55 & 3 & High \\
\hline 6 & $\begin{array}{l}\text { Allow students the opportunity } \\
\text { to use the Learning Resources } \\
\text { Room to search for the } \\
\text { information. }\end{array}$ & 2.76 & .52 & 4 & High \\
\hline 2 & $\begin{array}{l}\text { Using different evaluation } \\
\text { methods that suit the objectives } \\
\text { of the lesson. }\end{array}$ & 2.74 & .56 & 5 & High \\
\hline 1 & $\begin{array}{l}\text { The teacher employs modern } \\
\text { techniques in the education } \\
\text { process }\end{array}$ & 2.70 & .46 & 6 & High \\
\hline & $\begin{array}{c}\text { Total } \\
\end{array}$ & 2.76 & .39 & & High \\
\hline
\end{tabular}

Table (4) shows that the participants' response to all items was high with a mean $=(2,76)$. The two items $(5,4)$ were equal in the mean $(2,80)$ and the standard deviation (.45). They were of high degree of importance and the highest among all items. The item (4) agreed with the study of AlMedawi (2013), which emphasized the need of female teachers to pay attention to activating the extra-curricular activities for students. In addition, the item (5) agreed with the Al-Sakhil study (2010), which states "the importance of using knowledge in life fields." Item (1) came in the last rank, with a high degree of importance, with a mean $=2.70$ and agreed with the Al-Sakhil study (2010) which states "traditional teaching methods is one of the obstacles to school reform and development." The research attributes 
this to lack of awareness of some teachers with the importance of using technology and knowing its impact on the educational process. The remaining items ranged between (278) and (2.74).

Table (5):Means, standard deviations and ranks for participants' responses to:"Community partnership"

\begin{tabular}{|c|c|c|c|c|c|}
\hline $\begin{array}{c}\text { Item } \\
\text { No. }\end{array}$ & \multicolumn{1}{|c|}{ Item } & M & S.D & Rank & $\begin{array}{c}\text { Degree of } \\
\text { importance }\end{array}$ \\
\hline 4 & $\begin{array}{l}\text { Use multiple methods of } \\
\text { communication, such as: SMS } \\
\text { messages, e-mail, whatsapp. }\end{array}$ & 2.72 & .57 & 1 & High \\
\hline 1 & $\begin{array}{l}\text { Spreading a culture of } \\
\text { community partnership in the } \\
\text { surrounding community. }\end{array}$ & 2.66 & .59 & 2 & High \\
\hline 3 & $\begin{array}{l}\text { Spreading the school's message } \\
\text { in the surrounding community. }\end{array}$ & 2.62 & .57 & 3 & High \\
\hline 5 & $\begin{array}{l}\text { Benefiting from the human } \\
\text { cadres in society when planning } \\
\text { future school programs }\end{array}$ & 2.54 & .61 & 4 & High \\
\hline 6 & $\begin{array}{l}\text { The school offers seminars and } \\
\text { meetings for the local } \\
\text { community. }\end{array}$ & 2.49 & .65 & 5 & High \\
\hline 2 & $\begin{array}{l}\text { Engaging the local community in } \\
\text { developing a school vision. }\end{array}$ & 2.26 & .66 & 6 & High \\
\hline 7 & $\begin{array}{l}\text { The local community participates } \\
\text { in funding school programs. }\end{array}$ & 2.26 & .75 & 7 & High \\
\hline \multicolumn{7}{|c|}{ Total } & 2.50 & .47 & \multicolumn{1}{|c|}{ High } \\
\hline
\end{tabular}

Table (5) shows that the participants' response to all items was high with a mean $=(2,50)$. In the first place, the item (4) came with a high degree of importance, with a mean = (2.72). This is in accordance with Al-Shall \& Emara study (2009) which indicated "The importance of audio-visual and other modern means of communication". The item (7) came in the last rank with a high degree of importance, with a mean $=(2.26)$, and this agrees with Pond's study (2002) which indicated the necessity of providing and activating social participation and the importance of the private sector in funding education. The research attributes this to the reluctance of volunteer work and their preoccupation in a work with a direct economic return. The remaining items ranged between $(2,66)$ and $(2.26)$. 
Table (6):Means, standard deviations and ranks for participants' responses to: "Evaluation \& Accountability"

\begin{tabular}{|c|l|c|c|c|c|}
\hline $\begin{array}{c}\text { Item } \\
\text { No. }\end{array}$ & \multicolumn{1}{|c|}{ Item } & $M$ & S.D & Rank & $\begin{array}{c}\text { Degree of } \\
\text { importance }\end{array}$ \\
\hline 6 & $\begin{array}{l}\text { Developing self-monitoring } \\
\text { among school workers. }\end{array}$ & 2.92 & .34 & 1 & High \\
\hline 5 & $\begin{array}{l}\text { Linking workers 'incentives to } \\
\text { school productivity. }\end{array}$ & 2.88 & .33 & 2 & High \\
\hline 4 & $\begin{array}{l}\text { Continuous monitoring of } \\
\text { female workers performance }\end{array}$ & 2.82 & .44 & 3 & High \\
\hline 1 & $\begin{array}{l}\text { Using the principle of } \\
\text { accountability to ensure that } \\
\text { workers are committed to } \\
\text { school 2.80 }\end{array}$ & .45 & 4 & High \\
\hline 2 & $\begin{array}{l}\text { Implementing the regulations } \\
\text { related to the method of } \\
\text { rewarding/punishing workers. }\end{array}$ & 2.80 & .40 & 5 & High \\
\hline 3 & $\begin{array}{l}\text { The school performs self- } \\
\text { evaluation based on quality } \\
\text { assurance standards }\end{array}$ & 2.76 & .43 & 6 & High \\
\hline \multicolumn{1}{|c|}{ Total } & 2.83 & .26 & & High \\
\hline
\end{tabular}

Table (6) shows that the participants' response to all items was high with a mean $=(2,83)$. In the first place, Item (6) came with a high degree of importance, with a mean = (2.92). This is in accordance with Al-Shall \& \& Emara's study (2009) which indicated "The necessity of developing self-monitoring among school workers in schools". The item (3) came in the last rank with a high degree of importance, with a mean $=(2.83)$, and this agrees with the Al-Rayes study (2013) which indicated the importance of encouraging schools to perform self-evaluation in order to ensure continuous development through internal evaluation standards. The Study of Hartley (2003) also indicated that the accreditation and quality assurance system in the United Kingdom depends on some internal procedures such as evaluation of the quality of teaching and educational programs and academic review, while in Estonia it depends on self-evaluation. The remaining items ranged between $(2,88)$ and $(2.80)$. 
The second question: Are there statistically significant differences between the mean scores of the importance degree of the requirements of implementing school accreditation in development schools for girls in Tabuk from principals of development schools and quality and development supervisors' point of view attributable to the nature of work, years of experience?

1. Nature of work: To calculate the differences between participants' responses according to the nature of work, The Mann-Whitney test was used. Table (7) shows the result of this test.

Table (7)

\begin{tabular}{|c|c|c|c|c|c|c|}
\hline Dimension & Nature of work & M. & R.M. & S.R. & $\begin{array}{l}\text { Mann- } \\
\text { Whitney }\end{array}$ & Sig. \\
\hline Effective School & principal & 2.79 & 27.47 & 824.00 & \multirow{2}{*}{241} & \multirow{2}{*}{0.228} \\
\hline Leadership & supervisor & 2.60 & 22.55 & 451.00 & & \\
\hline \multirow{2}{*}{$\begin{array}{l}\text { The appropriate } \\
\text { school } \\
\text { environment }\end{array}$} & principal & 2.65 & 24.03 & 721.00 & \multirow[b]{2}{*}{256} & \multirow[b]{2}{*}{0.375} \\
\hline & supervisor & 2.68 & 27.7 & 554.00 & & \\
\hline $\begin{array}{l}\text { Teaching and } \\
\text { learning processes }\end{array}$ & \begin{tabular}{|l|} 
principal \\
supervisor
\end{tabular} & $\begin{array}{l}2.79 \\
2.72\end{array}$ & \begin{tabular}{l|}
23.97 \\
27.80
\end{tabular} & \begin{tabular}{|l|}
$\mathbf{7 1 9 . 0 0}$ \\
556.00
\end{tabular} & 254 & 0.314 \\
\hline \multirow{2}{*}{$\begin{array}{l}\text { Community } \\
\text { partnership }\end{array}$} & principal & 2.55 & 26.43 & 793.00 & \multirow{2}{*}{272} & \multirow{2}{*}{0.574} \\
\hline & supervisor & 2.42 & 24.10 & 482.00 & & \\
\hline \multirow{2}{*}{$\begin{array}{l}\text { Evaluation and } \\
\text { accountability }\end{array}$} & principal & 2.86 & 26.55 & 796.50 & \multirow{2}{*}{268} & \multirow{2}{*}{0.497} \\
\hline & supervisor & 2.79 & 23.93 & 478.50 & & \\
\hline \multirow{2}{*}{ Total } & principal & 2.73 & 26.17 & 785.00 & \multirow{2}{*}{280} & \multirow{2}{*}{0.691} \\
\hline & supervisor & 2.63 & 24.50 & 490.00 & & \\
\hline
\end{tabular}

Table (7) shows that there are no statistically significant differences at the level of (0.05) in the degrees of participants to the importance of the requirements of implementing the school accreditation in the development schools for girls in Tabuk according to the nature of work, which can be concluded that the nature of the work does not affect the degree of importance of the requirements of implementing school accreditation in development schools for girls. 
The research attributes this finding to the Ministry of Education's interest in spreading the culture of quality among school principals, and development and quality supervisors. Implementing quality assurance standards is of a high importance of school accreditation.

1. Years of experience: To calculate the differences between participants' responses according to years of experience, The Kruskal-wallis test was used. Table (8) shows the result of this test.

Table (8)

\begin{tabular}{|c|c|c|c|c|c|}
\hline Dimension & Experience & R.M. & Chi $^{2}$ & DF & Sig. \\
\hline \multirow{3}{*}{$\begin{array}{l}\text { Effective School } \\
\text { Leadership }\end{array}$} & $\begin{array}{l}\text { Lower than } 10 \\
\text { years }\end{array}$ & 12.00 & \multirow{3}{*}{2.620} & \multirow{3}{*}{2} & \multirow{3}{*}{0.270} \\
\hline & From 10 to less 15 & 24.43 & & & \\
\hline & 15 or more & 24.89 & & & \\
\hline \multirow{3}{*}{$\begin{array}{l}\text { The appropriate } \\
\text { school } \\
\text { environment }\end{array}$} & \begin{tabular}{|l}
$\begin{array}{l}\text { Lower } \\
\text { years }\end{array}$ \\
\end{tabular} & 17.50 & \multirow{3}{*}{1.455} & \multirow{3}{*}{2} & \multirow{3}{*}{0.483} \\
\hline & From 10 to less 15 & 28.36 & & & \\
\hline & 15 or more & 23.70 & & & \\
\hline \multirow{3}{*}{$\begin{array}{l}\text { Teaching } \\
\text { learning } \\
\text { processes }\end{array}$} & \begin{tabular}{|l}
$\begin{array}{l}\text { Lower } \\
\text { years }\end{array}$ \\
\end{tabular} & 11.83 & \multirow{3}{*}{5.386} & \multirow{3}{*}{2} & \multirow{3}{*}{0.068} \\
\hline & From 10 to less 15 & 31.43 & & & \\
\hline & 15 or more & 23.58 & & & \\
\hline \multirow{3}{*}{$\begin{array}{l}\text { Community } \\
\text { partnership }\end{array}$} & $\begin{array}{lll}\begin{array}{l}\text { Lower } \\
\text { years }\end{array} & \text { than } & \mathbf{1 0}\end{array}$ & 17.83 & \multirow{3}{*}{0.865} & \multirow{3}{*}{2} & \multirow{3}{*}{0.649} \\
\hline & From 10 to less 15 & 26.50 & & & \\
\hline & 15 or more & 24.03 & & & \\
\hline \multirow{3}{*}{$\begin{array}{l}\text { Evaluation and } \\
\text { accountability }\end{array}$} & \begin{tabular}{|l}
$\begin{array}{l}\text { Lower } \\
\text { years }\end{array}$ \\
\end{tabular} & 23.00 & \multirow{3}{*}{0.118} & \multirow{3}{*}{2} & \multirow{3}{*}{0.949} \\
\hline & \begin{tabular}{|l|} 
From 10 to less 15 \\
\end{tabular} & 22.71 & & & \\
\hline & 15 or more & 24.32 & & & \\
\hline \multirow{3}{*}{ Total } & $\begin{array}{l}\text { Lower than } 10 \\
\text { years }\end{array}$ & 14.50 & \multirow{3}{*}{1.963} & \multirow{3}{*}{2} & \multirow{3}{*}{0.375} \\
\hline & From 10 to less 15 & 27.71 & & & \\
\hline & 15 or more & 24.07 & & & \\
\hline
\end{tabular}

Table (8) shows that there are no statistically significant differences at the level of (0.05) in the degrees of participants to the importance of the requirements of implementing the school accreditation in the development schools for girls in Tabuk according to the years of experience. The research attributes these findings to the fact that the majority of participants are those with long 
experience. In addition, the experience may not depend on estimating the importance of the requirements of implementing the standards for accreditation due to the importance of Ministry of Education to qualify all female principals and supervisors to be aware of the requirements to achieve a competitive advantage. It also provide principals with educational expertise, skills and knowledge related to the culture of quality and accreditation through field work and some courses that female principals and supervisors may attend which do not require long experience in work.

\section{Summary of findings:}

1. The order of school accreditation requirements in the light of Arab and international experiences according to their importance from the viewpoint of development schools' principals and development \& quality supervisors in Tabuk as follows: evaluation and accountability, teaching and learning processes, effective school leadership, appropriate school environment and finally community partnership, where their means were as follows:

a) The participants' response to the dimension of "effective school leadership" was high with a mean $=(2,71)$.

b) The participants' response to the dimension of "appropriate school environment" was high with a mean $=(2,67)$.

c) The participants' response to the dimension of "teaching and learning processes" was high with a mean $=(2,76)$.

d) The participants' response to the dimension of "community partnership" was high with a mean $=$ $(2,50)$.

e) The participants' response to the dimension of "evaluation and accountability" was high with a mean $=(2,83)$. 
2. Findings revealed no statistically significant differences at the level of $(0,05)$ between participants' responses backed to the nature of work in all dimensions. There also were no statistically significant differences at the level of $(0,05)$ between participants' responses backed to years of experience in all dimensions.

\section{Recommendations:}

1. Establishing a school accreditation organization with setting standards in the Kingdom of Saudi Arabia in light of international school accreditation standards, provided to be appropriate to the reality of development schools in particular and public education schools in general.

2. Spreading a culture of quality and school accreditation among members of the school community through meetings, seminars and workshops.

3. Developing procedures that facilitate implementing school accreditation in development schools in particular and public education schools in general effectively, such as: training and developing educational principals to be able to carry out the task of continuous development and improvement, preparing school personnel on how to achieve school accreditation for their schools, developing technical and human equipment in the educational environment, allocating a budget to be spent in pursuit of school accreditation standards.

4. Setting a system to enhance school accreditation, such as: increasing the salaries of school employees who have accredited school, monitoring an annual award from the Ministry of Education for schools that achieve school accreditation standards, activating the use of social networking sites such as (Facebook and Twitter) to know the progress of schools in achieving quality and school accreditation. 


\section{References:}

Abdo, Abdul Karim. (2-5-2013). Requirements for qualifying public education schools in the Kingdom of Saudi Arabia to achieve school accreditation. A paper presented to the sixteenth annual meeting of the Justin Society at King Saud University. Riyadh. Kingdom of Saudi Arabia.

Al-Maliki, Hamdah Muhammad. (1431 AH). Implementing academic accreditation standards in public secondary education schools from the viewpoint of educational principals in Jeddah Governorate, unpublished Master Thesis, Umm Al-Qura University, Makkah Al-Mukarramah.

Al-Medawi, Abeer. (2-7-2013). A proposed mechanism for implementing school accreditation in public education institutions at the secondary stage in the Kingdom of Saudi Arabia in the city of Abha in the Asir region. A paper presented to the sixteenth annual meeting of the Justin Society at King Saud University. Riyadh. Kingdom of Saudi Arabia.

Al-Medini, Aisha Ahmed; Al-Omari, Maryam Zaid. (2-5-2013). School accreditation culture in the Kingdom of Saudi Arabia. A paper presentedto the sixteenth annual meeting of the Justin Society at King Saud University. Riyadh. Kingdom of Saudi Arabia.

Al-Mulhem, Nasser Abdulaziz (1428 AH). Academic accreditation for public education schools in the Kingdom of Saudi Arabia, unpublished Ph.D.Dissertation. King Saud University . Riyadh.

Al-Nabawi, Amin Muhammad. (2006). Academic accreditation for pre-university education schools in the United Arab Emirates. Journal of the College of Education, No. 19, pp. 130-207.

Al-Rayes, Nasser. (2-5-2013). A future strategic plan for school accreditation: importance, reasons, obstacles.A paper presented to the sixteenth annual meeting of the Justin Society at King Saud University. Riyadh. Kingdom of Saudi Arabia.

Al-Shall, Mahmoud; Emara, Sami (July 2009). Requirements for preparing basic education schools in Beheira Governorate to implement accreditation and quality assurance. Journal of the Faculty of Education, Zagazig University, No. 2, pp. 347-348.

Al-Shehri, Mohammed (2013). The possibility of implementing academic accreditation to all schools following the King Abdullah project for the development of education from the point of view of the school principals in Makkah Al-Mukarramah region, Riyadhunpublished Master Thesis, Umm Al-Qura, Makkah AlMukarramah. 
Al-Sherbeen, Ghada. (5-2-2013). Obstacles in achieving school accreditation standards in public education in the Kingdom of Saudi Arabia.A paper presented to the sixteenth annual meeting of the Justin Society at King Saud University. Riyadh. Kingdom of Saudi Arabia.

Al-Shonha, Abdel Moneim Hassan; Nada Abdel-Rahman Ahmed. (52-2013). Rehabilitation of public education schools to achieve the requirements of school accreditation. A field study in Port Said Governorate. A research presented at the sixteenth annual meeting of the Justin Society at the University of King Saud. Riyadh. Kingdom of Saudi Arabia.

Al-Sukhail, Muhammad Mustafa. (2010). School-centered reform and preparation for educational accreditation as one of the axes of the National Strategic Plan for Pre-University Education. Journal of the College of Education, Mansoura University, No. 73, Part Two, pp. 93-120.

Al-Turairy, Abdul Rahman. (2-5-2013). School accreditation: International models and experiences, and a proposed model for school accreditation in the Kingdom. A paper presented to the sixteenth annual meeting of the Justin Society at King Saud University, Riyadh. Kingdom of Saudi Arabia.

Al-Ziadat, Muhammad. (2008). An analytical study of the experiences of some Arab and international universities in achieving quality and academic accreditation.A paper presented to the strategic planning conference for higher education institutions in the Arab world. Cairo.

Arab Bureau of Education for the Gulf States (2011). Building an integrated organizational model for school accreditation in the member states of the Arab Bureau of Education for the Gulf States. Riyadh.

Azab, Muhammad Ali; Morsi, Saeed Mahmoud. (2010). Quality and accreditation for pre-university education institutions, constituents, obstacles and proposals. Journal of the College of Education, Volume 20. Number 4.

Dirndi, Ekbal; Hawk, Tahira. (28-29 Rabi 'al-Akhir 1428 AH). An exploratory study of the opinions of some officials and faculty members on the procedures for implementing evaluation activities and quality assurance in Saudi universities and colleges. A paper presented for the fourteenth annual meeting of the Saudi Society for Educational and Psychological Sciences (Justin) Al-Qassim. Kingdom of Saudi Arabia. 
Gollnic,D.(2003).Introduction to NCATE Accreditation System,18 paper presented at the Institutional Orientation and Professional Development Conference, Arlington Virginia.

Hartly , R. and Virkus ,S., ( 2003), Approaches to Quality Assurance and Accreditation of LIS programs : Experiences from Estonia and United Kingdom, Journal of Education for information, Vol .21.

Hussein, Bashir. (2009). Accreditation for Educational Institutions Introduction to Education Reform. A research presented to the 7th International Conference on Education at the beginning of the third millennium of quality - lifelong learning - Institute of Educational Studies. Cairo University.

Ministry of Education (1433 AH). A guide for educational supervision in the school development model. Riyadh, Tatweer Company.

Ministry of Education (1433 AH). School development model. Riyadh, Tatweer Company.

Pond, W .(2002). Twenty First Century Education and Training Implications for Quality Assurance, The Internet and higher education, Vol.4.p.185

Qatar Supreme Education Council. (2014). Conditions for nomination for the National School Accreditation (QNSA). Retrieved on (6/9/2014), from http://cutt.us/Rxha.

Sharif, Muhammad Sharif. (September 2011). Requirements for activating the efforts of the National Authority to ensure the quality of education and accreditation in the reality of preuniversity education institutions. Journal of Culture and Development, No. 48, Part 2. 